\title{
PERTUMBUHAN DAN SINTASAN BENIH IKAN GURAME (Osphronemus gouramy) PADA BERBAGAI DOSIS AIR PERASAN TEMULAWAK
}

\author{
Growth and Survival Seed Carp Fish (Osphronemus gouramy) On Various Water Juice of Curcuma
}

\author{
Yulian Tri Anggara' ${ }^{1}$, Sugeng Prayogo ${ }^{2}$, dan Wiwik Argianti² \\ ${ }^{1}$ Alumni Fakultas Perikanan Universitas PGRI Palembang \\ ${ }^{2}$ Staf Pengajar Fakultas Perikanan Universitas PGRI Palembang
}

\begin{abstract}
Abstrak
Penelitian ini bertujuan untuk mengetahui pertumbuhan dan sintasan benih Ikan Gurame (Osphronemus gouramy) dengan penambahan air perasan Temulawak pada pakan. Ikan uji yang digunakan adalah Ikan Gurame dengan panjang awal 1,8 -2,2 cm dengan berat awal 0,25 -0,35 gram, yang dipelihara dalam bak plastik berukuran 40 × 30 × $25 \mathrm{~cm}$. Metode penelitian yang digunakan adalah metode eksperimen dengan menggunakan Rancangan Acak Lengkap (RAL), terdiri 4 perlakuan dengan 3 kali ulangan. Hasil penelitian menunjukkan, bahwa perlakuan D (Penambahan air perasan Temulawak 6\% dari jumlah pakan) memberikan pengaruh yang berbeda terhadap pertumbuhan benih Ikan Gurame. Pada perlakuan D memberikan pertambahan pertumbuhan terbaik yaitu panjang mutlak sebesar $4,11 \mathrm{~cm}$ dengan berat sebesar 3.29 gr dan nilai SR sebesar 78.3\%. Untuk perlakuan C pertambahan pertumbuhan panjang mutlak sebesar $4.07 \mathrm{~cm}$ dengan berat 3.14 gr dan nilai SR sebesar $80 \%$. Perlakuan B pertambahan pertumbuhan panjang mutlak sebesar $4.06 \mathrm{~cm}$ dengan berat 3.16 gr dan nilai SR sebesar 78.3\%. Sedangkan perlakuan A memberikan pertambahan pertumbuhan dan sintasan terendah yaitu panjang mutlak sebesar $3.97 \mathrm{~cm}$ dengan berat sebesar 2.99 gr dan nilai SR sebesar 76.7\%. Hasil pengamatan kualitas air yang diukur selama penelitian masih dalam batas toleransi untuk tumbuh dan berkembang benih Ikan Gurame. Dari hasil penelitian yang dilakukan untuk penambahan air perasan Temulawak pada pakan sebaiknya menggunakan dosis $5 \%$, karena memberikan rata-rata pertumbuhan panjang akhir sebesar $6,03 \mathrm{~cm}$ dengan berat rata-rata sebesar 3,43 gram dan sintasan yang sebsar $80 \%$.
\end{abstract}

Kata Kunci: Pertumbuhan, Sintasan, Ikan Gurame, Temulawak

\begin{abstract}
This study of determine the growth and survival rate of fish seed Carp (Osphronemus gouramy) with the addition of the juice of Curcuma on feed. Test fish were used is Carp fish with 1,8-2,2 cm long outset with initial weight of 0,25-0,35 grams, which is kept in a plastic tub measuring $40 \times 30 \times 25 \mathrm{~cm}$. The method used is an experimental method using a completely randomized design (CRD), comprised 4 treatments with 3 replications. The results showed that treatment D (Addition of Ginger juice of $6 \%$ of total feed) have different effects on the growth of fish seed Carp. At treatment D gives long added growth in the absolute best of 4,11 cm with a weight of 3,29 grams and Survival value of $78.3 \%$. For treatment $C$ accretion absolute growth of $4,07 \mathrm{~cm}$ long with a weight of 3,14 $\mathrm{g}$ and the value by $80 \%$ survival rate. Treatment of $B$-added growth in the absolute length of 4,06 cm with a weight of 3,16 grams and Survival value of 78.3\%. Treatment A while providing the lowest survival rate of growth and increase the absolute length of $3,97 \mathrm{~cm}$ with a weight of 2,99 grams and Survival value of 76.7\%. Observations of water quality measured during the study are still within tolerable limits to grow and thrive Carp Fish seed. From the results of research conducted for the addition of the juice of Curcuma on feed should use a dose of 5\%, as it gives an average growth of 6,03 cm final length with an average weight of 3,43 grams and a survival rate of $80 \%$.
\end{abstract}

Keywords: Growth, Survival Rate, Carp Fish, Curcuma 


\section{PENDAHULUAN}

Ikan Gurame (Osphronemus gouramy) merupakan jenis ikan air tawar komoditas unggulan yang dikembangkan dalam Revitalisasi Pembangunan Perikanan Budidaya 2011 - 2012 oleh Kementrian Kelautan dan Perikanan. Penentuan komoditas unggulan tersebut karena teknologi budidaya ikan Gurame sudah dikuasai dan sudah berkembang di masyarakat (Departemen Kelautan dan Perikanan, 2012). Permasalahan spesifik dalam pemeliharaan benih ikan Gurame yaitu pertumbuhan yang lambat (Adnan, et al., 2002). Menurut Sendjaya dan Rizki (2002) permasalah benih ikan Gurame yaitu benih ikan Gurame mudah terserang penyakit yang menyebabkan pertumbuhan ikan Gurame menjadi terganggu dan lambat (Sendjaya dan Rizki, 2002). Untuk memacu pertumbuhan pada stadia benih ikan Gurame, alternatif yang dapat dilakukan salah satunya dengan penambahan air perasan Temulawak pada pakan ikan. Air perasan Temulawak berfungsi untuk meningkatkan nafsu makan ikan dan diharapkan dapat meningkatkan pertumbuhan (kualitas dan kuantitas benih ikan). Menurut Limananti dan Triratnawati (2003) Temulawak (Curcuma xanthorrhiza) berfungsi untuk meningkatkan nafsu makan, anti bakteri dan anti oksida. Selain itu Temulawak dapat merangsang fungsi pankreas, berkemampuan merangsang perjalanan sistem hormon metabolisme fisiologi tubuh dan menjaga dan meningkatkan hati atau lever (hepatoprotektor). Bagian yang berkhasiat dari Temulawak adalah rimpangnya yang mengandung berbagai komponen kimia di antaranya protein, zat kuning kurkumin, pati dan minyak atsiri (Taryono et al., 1987). Dari hasil penelitian Novriadi (2010) pemberian 5\% ekstrak Temulawak memberikan peningkatan pertumbuhan panjang dan berat pada ikan Kakap merah (Lutjanus johnii). Maka perlu dilakukan penelitian tentang pengaruh pemberian air perasan Temulawak ke pakan terhadap pertumbuhan dan sintasan benih ikan Gurame (Osphronemus gouramy).

\section{BAHAN DAN METODE}

Penelitian ini dilakukan di Kelompok Tani Tambak Mulia Jln. Kapten Abdullah Lrg. Mulia 1 No. 1168 Rt.017/006 Kelurahan Talang Bubuk Plaju Kota Palembang.

Benih ikan Gurame yang digunakan berukuran panjang awal 1,8 -2,2 cm dengan berat awal 0,25 -0,35 gram. Wadah yang digunakan dalam penelitian ini nerupa bak plastik berukuran
40 x 30 x $25 \mathrm{~cm}$ sebanyak 12 buah. Setiap bak diisi air sebanyak 20 liter atau setinggi $17 \mathrm{~cm}$, kemudian diberi aerasi. Setiap bak diisi 20 ekor atau 1 ekor/liter. Pakan yang digunakan merupakan pellet komersial yang telah dicampur dengan Air Perasan Temulawak sesuai dosis yang digunakan dalam penelitian yaitu 4\%, 5\% dan $6 \%$ dari jumlah pakan yang diberikan. Pemberian pakan dilakukan tiga kali sehari yaitu pada pagi pukul $08.00 \mathrm{WIB}$, siang pukul 12.00 WIB dan sore 16.00 WIB. Dengan dosis pemberian $5 \%$ dari dari total berat badan (biomassa).

Metode penelitian yang digunakan adalah metode eksperimen dengan menggunakan Rancangan Acak Lengkap (RAL) terdiri atas 4 taraf perlakuan dengan masig-masing dilakukan 3 kali pengulangan. Perlakuan yang dicobakan adalah A (Kontrol atau tanpa penambahan air perasan Temulawak), B (Penambahan air perasan Temulawak 4\% dari jumlah pakan), C (Penambahan air perasan Temulawak 5\% dari jumlah pakan) dan D (Penambahan air perasan Temulawak $6 \%$ dari jumlah pakan). Parameter yang diamati meliputi pertumbuhan, sintasan (SR) dan kualitas air. Pengamatan pertumbuhan meliputi pertumbuhan berat dan panjang. Perhitungan pertumbuhan berat dan panjang benih Ikan Gurame (Osphronemus gouramy) dilakukan seperti yang di kemukakan Effendie (1997) sebagai berikut:

Perhitungan Pertambahan Berat Mutlak:

$\mathbf{W}=\mathbf{W t}-\mathbf{W o}_{\mathbf{0}}$

Keterangan:

$\mathrm{W}=$ Pertambahan berat (gr)

$\mathrm{Wt}=$ Berat rata-rata akhir benih (gr)

$\mathrm{Wo}_{\mathrm{o}}=$ Berat rata-rata awal benih $(\mathrm{gr})$

Perhitungan Pertambahan Panjang Mutlak :

$\mathbf{T}=\mathbf{L t}-\mathbf{L o}$

Keterangan:

$\mathrm{T}=$ Pertambahan panjang $(\mathrm{cm})$

$\mathrm{Lt}=$ Panjang rata-rata benih pada akhir $(\mathrm{cm})$

Lo $=$ Panjang rata-rata benih pada awal $(\mathrm{cm})$

Untuk sintasan (SR) dihitung dengan rumus Effendie (1997):

$$
\mathrm{SR}=\frac{\mathrm{Nt}}{\mathrm{No}}^{\mathrm{x}} 100 \%
$$

Keterangan :

$\mathrm{SR}=$ Derajat kelulusan hidup (\%)

$\mathrm{Nt}=$ Jumlah biota pada akhir pemeliharaan (ekor) 


\section{No = Jumlah biota pada awal penebaran (ekor)}

\section{HASIL DAN PEMBAHASAN}

Data hasil penelitian dianalisis dengan menggunakan analisis sidik ragam (ANSIRA) untuk mengetahui pengaruh perlakuan yang diberikan terhadap pertumbuhan dan sintasan benih Ikan Gurame. Apabila hasil analisa sidik ragam (ANSIRA) menunjukkan nilai $F_{\text {hitung }}>$ $\mathrm{F}_{\text {tabel }}$ pada $\alpha=0,05 \%$ dan $0,01 \%$ maka akan diuji lanjut. Untuk nilai KK (Koefisien Keragaman) 15\% maka akan diuji lanjut dengan mengunakan BNJ (Beda Nyata Jujur), bila nilai KK 5-10\% maka akan diuji lanjut dengan mengunakan BNT (Beda Nyata Terkecil) dan apabila nilai KK > $10 \%$ maka akan diuji lanjut dengan mengunakan Duncan. Sedangkan kualitas air akan diuji secara deskritif.

Berdasarkan data hasil dari uji sidik ragam (ANSIRA), diketahui bahwa terdapat pertumbuhan panjang dan berat yang lebih baik pada Ikan Gurame (Osphronemus gouramy) yang diberikan air perasan Temulawak dibandingkan dengan Ikan Gurame (Osphronemus gouramy) Kontrol (tanpa perlakuan).

Penambahan air perasan Temulawak pada pakan memberikan pertambahan rataan pertumbuhan panjang mutlak terbaik yaitu pada perlakuan D sebesar $4,11 \mathrm{~cm}$ dengan berat rerata 3,29 gram. Pada penelitian Darmawangsa (2008) benih ikan Gurame yang diberi pakan berupa pellet menghasilkan pertumbuhan benih ikan Gurame yaitu rata-rata panjang mutlak sebesar $2,89 \mathrm{~cm}$ dengan berat rata-rata 2,00 gram.

Hal ini diduga penambahan air perasan Temulawak pada pakan ikan meningkatkan kandungan gizi pada pakan ikan, antara lain peningkatan protein dan lemak sebesar 1-2\%. Menurut Sumiati (1997) dalam Laili (2007), kandungan senyawa yang terdapat pada rimpang Temulawak antara lain karbohidrat $58,24 \%$, lemak $12,10 \%$, protein 2,90\%, kadar air $10 \%$ dan abu 4,90\%. Kandungan Temulawak tersebut dimanfaatkan ikan untuk tumbuh. Menurut Budianto (2009) protein merupakan suatu zat makanan yang sangat penting bagi tubuh, karena zat ini disamping berfungsi sebagai zat pembangun dan pengatur, Protein adalah sumber asam - asam amino yang mengandung unsur $\mathrm{C}$, $\mathrm{H}, \mathrm{O}$ dan $\mathrm{N}$ yang tidak dimiliki oleh lemak atau karbohidrat. Sedangkan menurut NRC (1993) Lemak mengandung energi dua kali lipat dibandingkan dengan protein dan karbohidrat. Jika lemak yang dikonsumsi dapat memberikan energi yang cukup untuk kebutuhan metabolisme, maka sebagian protein yang di konsumsi dapat digunakan tubuh untuk pertumbuhan dan bukan digunakan sebagai sumber energi. Dan karbohidrat merupakan salah satu jenis zat gizi, yang fungsi utama karbohidrat adalah penghasil energi di dalam tubuh (NRC 1993).

Berdasarkan hasil uji sidik ragam (ANSIRA) nilai $\mathrm{F}$ hitung dari sintasan dibawah nilai $\mathrm{T}$ Tabel sehingga tidak berbeda nyata. Akan tetapi sintasan pada ikan yang diberikan perlakuan air perasan Temulawak juga memberikan hasil yang cukup baik dibandingkan pakan yang tidak diberikan air perasan Temulawak. Sintasan atau kelangsungan hidup benih Ikan Gurame (Osphronemus gouramy) yang tertinggi yaitu pada perlakuan $\mathrm{C}$ dengan nilai rata-rata sintasan $80 \%$, dan untuk perlakuan B dan perlakuan D memiliki nilai rata-rata sintasan yang sama yaitu 78,33\%. Sedangkan nilai rata-rata yang terendah terdapat pada perlakuan A (terkontrol) dengan nilai rata-rata 76,67\%. Pada penelitian Darmawangsa (2008) benih ikan Gurame yang diberi pakan berupa pellet menghasilkan sintasan berkisar $72,84 \%$ $79,63 \%$.

Hal ini diduga karena didalam rimpang Temulawak terdapat kandungan kurkumin, dimana kandungan tersebut berfungsi sebagai anti bakteri dan anti oksida (Limananti dan Triratnawati, 2003), sehingga benih Ikan Gurame (Osphronemus gouramy) tahan terhadap penyakit.

Pada pelakuan D mempunyai nilai sintasan lebih rendah dibandingkan nilai sintasan pada perlakuan $\mathrm{C}$, ini karena penambahan air perasan Temulawak di pelakuan D lebih banyak dibandingkan pada perlakuan C. Selain kandungan protein, lemak, karbohidrat dan kurkumin, Temulawak juga mengandung minyak atsiri. Dimana minyak atsiri memiliki bau khas aromatik, rasa agak pahit dan mempunyai sifat panas. Efek farmakologis inilah yang diduga dapat mendorong ikan menjadi stress pada dosis tertentu (Laili, 2007). Menurut Guanther (1987) dalam Rochani (2000), menyatakan bahwa efek minyak atsiri mampu memacu syaraf otonom suatu organisme. Oleh karena minyak atsiri mengandung senyawa kimia (golongan terpen) yang dapat menurunkan motilitas (kemampuan bergerak) dan daya hidup organisme.

Selain itu kandungan minyak atsiri yang berlebihan dapat menyebabkan terganggunya sistem pernafasan, yang menyebabkan ikan mudah stress sehingga melemahkan sistem pertahanan tubuh ikan. Seperti yang dikemukakan oleh Brown et. al., (1980) dalam 
Rochani (2000) menyatakan bahwa stress pada ikan akan melemahkan mekanisme pertahanan tubuh ikan.

Parameter kualitas air yang diukur selama penelitian masih dalam batas kemampuan toleransi untuk pertumbuhan Ikan Gurame (Osphronemus gouramy). Menurut Effendie (2003) menyatakan selain faktor ketersedian pakan yang dapat memenuhi kebutuhan nutrisi, kondisi media pemeliharaan juga berperan penting untuk meningkatkan pertumbuhan dan kelangsungan hidup benih Ikan Gurame (Osphronemus gouramy). Saat pemeliharaan suhu pada media pemeliharaan masih dalam batas toleransi untuk pertumbuhan ikan yaitu berkisar $26^{\circ} \mathrm{C}-28^{\circ} \mathrm{C}$. Menurut Badan Standarisasi Nasional (2000) benih ikan gurame dapat hidup baik pada suhu $25-30^{\circ} \mathrm{C}$. Selama pemeliharaan $\mathrm{pH}$ pada media hidup ikan masih dalam batas toleransi untuk pertumbuhan ikan berkisar antara 6,7-7,0. Menurut Sendjaya dan Rizki (2002), pH air yang sesuai untuk benih gurame berkisar 6,5 - 7,5. Pernyataan ini didukung juga oleh Khairuman dan Amri (2003) derajat keasaman $(\mathrm{pH})$ yang baik untuk budidaya gurame adalah 5-9. Selain itu kandungan oksigen terlarut juga harus memenuhi kebutuhan benih Ikan Gurame (Osphronemus gouramy), oksigen terlarut saat pemeliharaan masih dalam batas toleransi berkisar 3,12-3,98 $\mathrm{mgL}^{-1}$. Menurut Puspowardoyo dan Siregar (1992) kandungan oksigen terlarut yang baik untuk budidaya ikan Gurame adalah $3-5 \mathrm{mgL}^{-1}$. Selain parameter suhu, $\mathrm{pH}$ dan Oksigen terlarut (DO) juga dilakuan pengujian amoniak $\left(\mathrm{NH}_{3}\right)$. Jumlah amoniak pada media pemeliharaan berkisar $0,012-0,104 \mathrm{mgL}^{-1}$. Amoniak merupakan racun bagi ikan sekalipun pada konsentrasi yang sangat rendah. Namun toleransi amoniak bagi biota perairan termasuk ikan Gurame adalah tidak lebih dari 0,2 $\mathrm{mgL}^{-1}$ (Effendi, 2003).

\section{KESIMPULAN}

Perlakuan C (Penambahan air perasan Temulawak 5\% dari jumlah pakan) merupakan dosis yang tepat karena memiliki nilai sintasan yang tertinggi sebesar $80 \%$, dan rata-rata pertumbuhan panjang mutlak sebesar $4,07 \mathrm{~cm}$ dengan berat rata-rata 3,2 gram.

\section{DAFTAR PUSTAKA}

Adnan, D.W., Martawijaya, E.L., dan Setiawan, B.D. 2002. Pembenihan Gurame di Dalam Akuarium. Agro Media Pustaka. Jakarta.
Budianto, A.K. 2009. Dasar-Dasar Ilmu Gizi. Cetakan keempat. Malang : UMM Press.

Darmawangsa, G. M. 2008. Pengaruh Padat Penebaran 10, 15 Dan 20 Ekor/l Terhadap Kelangsungan Hidup Dan Pertumbuhan Benih Ikan Gurami (Osphronemus goramy Lac) Ukuran $2 \mathrm{~cm}$. Skripsi. Institut Pertanian Bogor. (Tidak dipublikasikan).

Departemen Kelautan dan Perikanan, 2012. Upaya Pemerintah Untuk Meningkatkan Produksi Perikanan Budidaya. Jakarta.

Ditjenkan. 2000. Induk Ikan Gurame (Osphronemus gouramy) SNI 01- 6485.12000. Direktorat Jendral Perikanan Jakarta.

Effendie, M. I. 1997. Biologi Perikanan. Yogyakarta: Yayasan Pustaka Nusatama.

Effendi, H. 2003. Telaah Kualitas Air Bagi Pengelolah Sumber Daya dan Lingkungan Perairan. Jakarta.

Khairuman,SP. dan Amri K. 2003. Pembenihan dan Pembesaran Gurame Secara Intensif. Agromedia Pustaka.

Laili, U. 2007. Pengaruh Pemberian Ekstrak Temulawak (Curcuma xanthorrhiza Roxb) Terhadap Prevalensi Kelulusan Hidup Ikan Mas (Cyprinsus carpio) yang Diinfeksi Bakteri Aeromonas hydrophyla. Jawa Timur. Skripsi. Universitas Islam Negeri Malang. (Tidak dipublikasikan).

Limananti, A. I dan Triratnawati, A. 2003. Ramuan Jamu Cekok sebagai Penyembuh Kurang Nafsu Makan Pada Anak: Suatu Kajian Etnomedisin. Makara kesehatan. Jogjakarta: UGM.

National Research Council (NRC), Subcommite on Warmwater Fish Nutrition. 1993. Nutrient requirements of fish. Washington DC: National Academy of science, 114 pp.Peres H. and Teles AO. 1999. Effect of dietary lipid level on growth performance and feed utilization by European sea bass juveniles (Dicentrarchus labrax). Aquculture.

Novriadi, R. 2010. Aplikasi Ekstrak Temuawak (Curcuma xanthorrhiza Roxb) Pada Pakan Studi Komparasi Mutu Pakan Terhadap Pertumbuhan Ikan Kakap Merah (Lutjanus johnii). Makalah Penelitian. Balai Budidata Laut Batam.

Puspowardoyo, H. dan Siregar. 1992. Membudidayakan Ikan Gurame Secara Intensif. Kanisius.

Rochani. 2000. Pemanfaatan Rimpang Kunyit (Curcuma domestika) sebagai Alternatif Pengendali Penyakit Aeromonas hydrophila pada Ikan Mas (Cyprinus 
carpio L.). Tesis. Program Pascasarjana. Universitas Brawijaya. Malang.

Sendjaya, T dan Rizki. 2002. Usaha Pembenihan Gurame. Penebar Swadaya.

Taryono., E. M. Rahmat, S dan A. Sardina, 1987.

Plasma Nutfah Tanaman Temu-temuan.

Edisi Khusus Ballittro. 
Jurnal Ilmu-Ilmu Perikanan dan Budidaya Perairan Volume 13, Nomor 2, Desember 2018 